Vol. 2, No. 2, Juli - Desember 2018

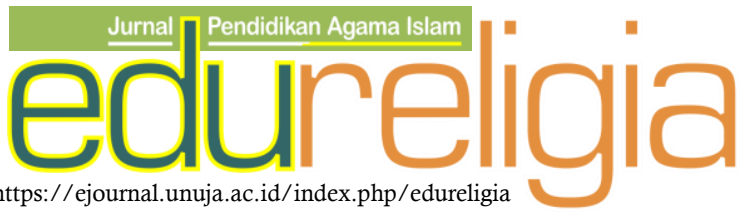

\title{
KEPEMIMPINAN TRANSFORMASIONAL KEPALA \\ MADRASAH DALAM MENINGKATKAN MUTU MADRASAH (STUDI KASUS DI MA MATHOLI'UL HUDA BUGEL JEPARA)
}

\author{
Subaidi ${ }^{1}$; \\ Universitas Islam Nahdlatul Ulama (UNISNU) Jepara
}

\section{Info Artikel \\ Sejarah Artikel: \\ Diterima; Juni 2018 \\ Disetujui; Juli 2018 \\ Dipublikasikan; Agustus 2018}

Keywords:

transformational

leadership, middle school

head, quality

\begin{abstract}
This study describes the principal's transformational leadership in improving the quality of madrasas conducted at $M A$ Matholi'ul Huda Bugel Jepara. This research is a qualitative research. Collecting data through observation, interviews, and document review. Data analysis in this study uses interactive models such as those developed by Miles and Huberman. The results of the study indicate that; first, the value of transformational leadership which includes four aspects, namely: Idealized Influence or Inspirational Motivation, Intellectual stimulation or intellectual stimulation, Individualized consideration or individual consideration; secondly, the leadership of the head of the madrasa Aliyah Matholi'ul Huda Bugel Jepara has built trust with teachers and employees, through a reliable example of the madrasa principals, the compatibility between what is said and done, the opportunity for teachers and employees to express opinions, give opportunity to take part in duties and responsibilities, also take part in various trainings; third, the quality of the MA Matholi'ul Huda Bugel Kedung Jepara with the title of "very good" with evidence of the superiority of the results of the national and madrasah examinations in the last 3 years always get 100\% graduation with an average score of 8.50, many students have achieved achievements Provincial and national level competitions
\end{abstract}

(C) 2018 Fakultas Agama Islam Universitas Nurul Jadid

Korespondensi:

ISSN 2549-4821

${ }^{1}$ Universitas Islam Nahdlatul Ulama (UNISNU) Jepara E-ISSN 2579-5694 


\section{PENDAHULUAN}

Setipa organisasi, termasuk lembaga pendidikan memiliki tujuan untuk mencapai kinerja yang optimal. Peningkatan kinerja yang optimal tidak terlepas dari kepuasan kerja anak buah selaku orang yang dipimpimpin dalam sebuah organisasi atau lembaga pendidikan Islam menuju optimalisasi lembaga pendidikan Islam yang bermutu. Pemimpin dalam melaksanakan tugas menejerial kebanyakan pada konteks budaya organisasi selama ini hanya menerapkan pengarahan satu arah kepada anak buah karena ingin serba cepat. Hal ini akan membuat semua anak buah "mengikuti saja", dan apabila hasil dari perintah atasan berdampak buruk, maka mereka akan menyalahkan manajer mereka dan tidak mau bertanggungjawab atas konsekuennya. Hal demikian terjadi karena mereka tidak memiliki "rasa andarbeni" dari perintah (keputusan) yang diberikan atasan. Jika hal demikian terjadi secara terus menerus dan dibiarkan maka akan membuat komitmen mereka rendah, tidak mandiri dan tidak menjadi kreatif sehingga pengembangan diri mereka pun di tempat kerja berhenti.

Apabila setiap pemimpin tetap terbiasa dengan budaya kepemimpinan yang selalu memberi perintah dan melakukan secara terus menerus tanpa melakukan pengembangan pada anak buah menuju sebuah organisasi yang bermutu, maka dikhawatirkan dalam jangka panjang akan menurunkan kinerja organisasi yang berdampak pada menurunnya daya saing lembaga itu sendiri. Banyak sekolah dan madrasah yang tidak efektif dan mulai kehilangan daya saing.

Oleh karenanya perlu memperbaiki kinerja melalui proses rekayasa ulang lembaga, baik dalam budaya organisasi, struktur organisasi, teknologi dan kompetensi SDM (Wijayanto, 2012). Melalui tulisan ini, penulis ingin mengajak para pemimpin, manajer dan pelaku pendidikan lainnya yang memiliki anak buah untuk melakukan perubahan budaya dalam menerapkan model kepemimpinan yang melibatkan anak buah dalam mengambil suatu keputusan, jangan mengimplementasikan model kepemimpinan yang hanya "memberi perintah" saja tetapi harus menyesuaikan dengan model kepemimpinan yang sesuai dengan trend organisasi modern saat ini, yakni gaya kepemimpinan dan manajemen yang lebih banyak melakukan pendelegasian dan pemberdayaan (Wijayanto, 2012). Pengelolaan madrasah mutu memberikan kepercayaan yang luas kepada madrasah untuk mengoptimalkan sumber daya yang tersedia di madrasah bagi tercapainya tujuan pendidikan yang diharapkan. Hal yang sama juga diungkapkan oleh Mulyasa (2011: 24), bahwa kepala madrasah merupakan salah satu komponen pendidikan yang paling berperan dalam meningkatkan kualitas pendidikan. Dalam rangka melaksanakan pendidikan yang berbasis madrasah, kepala madrasah, sebagai pemimpin dituntut memiliki kemampuan mengelola madrasah dengan baik. Bagi kepala madrasah, manajemen berbasis madrasah merupakan tantangan baru bagi kepemimpinannya (Jabar, 2014: 123).

Dalam dunia pendidikan, sejalan dengan upaya pembaharuan, model kepemimpinan juga penting untuk diformulasikan. Kepemimpinan transformasional berdasarkan konseptual melalui kharismatik, motivasi inspirasional, stimulasi intelektual, dan perhatian terhadap individu diyakini akan mampu melahirkan pemikiranpemikiran yang mengandung pada jangkauan kedepan, azaz demokrasi dan transparan secara utuh. Oleh karena itu perlu diadopsi ke dalam model kepemimpinan kepala madrasah. Kepala madrasah merupakan ujung tombak dan tulang punggung dinamika lembaga. Kemajuan organisasi madrasah sangat tergantung terhadap eksistensi sosok seorang kepala. Oleh karenanya, kepala madrasah haruslah sosok yang dinamis, kreatif, dan kompetitif, serta tidak mudah menyerah, patah semangat dan lemah cita-cita.

Manajemen mutu merupakan sebuah filosofi metodologi tentang perbaikan manajemen madrasah secara terus menerus yang dapat memberikan seperangkat alat praktis kepada setiap institusi pendidikan dalam memenuhi kebutuhan, keinginan dan harapan para pelanggan pada saat ini maupun pada masa yang akan datang. Karena konsep dasar manajemen mutu adalah mempertahankan dan meningkatkan mutu secara keseluruhan sehingga memungkinkan produk dan jasa sebuah organisasi, termasuk organisasi pendidikan berada pada tingkat yang paling ekonomis yang dapat memberikan kepuasan kepada pelanggan secara keseluruhan. Manajemen mutu memperkenalkan pengembangan proses, produk, dan pelayanan sebuah organisasi secara sistematik dan berkesinambungan. Pendekatan semacam ini melibatkan dari pihak-pihak dan memastikan bahwa pengalaman dan ide-ide mereka memiliki 
sumbangan dalam pengembangan mutu lembaga, termasuk lembaga pendidikan madrasah (Zazin, 2011: 58-59).

Masalah yang dikaji dalam penelitian ini adalah kepemimpinan transformasional kepala madrasah dalam meningkatkan mutu madrasah di MA Matholi'ul Huda Bugel Jepara. Untuk dapat mengetahui hal tersebut digali melalui perntanyaan sebagai berikut: nilai kepemimpinan apa yang diyakni dan diperjuangkan kepala madrasah untuk membangun mutu madrasah di MA Matholiul Huda Bugel Kedung Jepara; bagaimana kepala madrasah membangun rasa saling percaya antara guru dan karyawan; bagaimana kepala madrasah meningkatkan mutu madrasah. Tulisan ini bermaksud mendeskripsikan kepemimpinan transformasional kepala madrasah dalam meningkatkan mutu madrasah di madrasal Aliyah Matholi'ul Huda Bugel Jepara.

\section{METODE PENELITIAN}

Jenis penelitian yang digunakan adalah kualitatif. Sedangkan pendekatan yang digunakan pendekatan studi kasus. Kasus yang diteliti adalah keberhasilan kepemimpinan kepala madrasah MA Matholi'ul Huda Bugel Kedung Jepara dalam menghadapi masa-masa sulit, mampu menjadikan madrasah menjadi salah satu madrasah unggul dengan prestasi membanggakan. Lokasi penelitian di MA Matholi'ul Huda Bugel Kedung Jepara. Penelitian ini dilaksanakan pada bulan April - Juni 2018. Teknik pengumpulan data dalam penelitian ini menggunakan observasi, wawancara, dan kajian dokumen. Sedangkan analisis datanya menggunakan model interaktif seperti yang dikembangkan oleh Miles dan Huberman (Miles, 1994: 12), terkait dengan kepemimpinan transformasional kepala madrasah dalam meningkatkan mutu madrasah di MA Matholi'ul Huda Bugel Kedung Jepara.

\section{KAJIAN TEORI}

Menurut Lam dan O'Higgins (2012) bahwa kepemiminan transformasional diartikan sebagai model kepemimpinan yang mencari potensi dan motivasi dari pengikut, berusaha untuk memenuhi kebutuhan mereka yang lebih tinggi, dan melibatkan pengikut sepenuhnya dalam pengambilan suatu keputusan. Pemimpin transformasional menyebabkan pengikutnya untuk menjadi sangat berkomitmen untuk mencapai misi mereka sehingga mereka dapat melakukan pengorbanan pribadi yang signifikan dalam kepentingan organisasi (Munthe, 2015: 273)
Menurut Lam dan O'Higgins (2012) bahwa setidaknya ada 4 komponen sebagai ciri utama dari kepemmpinan transformasional: 1) berkharisma. Artinya, pemimpin menampilkan keyakinan, menekankan kepercayaan, dan mengambil bagian untuk menyelesaikan isu-isu yang sulit, mereka menyajikan nilai-nilai yang paling penting, dan menekankan pentingnya tujuan, komitmen, dan konsekuen keputusan yang etis. Pemimpin digambarkan sebagai model yang menghasilkan kebanggaan, loyalitas, kepercayaan, dan keselarasan untuk tujuan bersama; 2) menjadi motivator dan sumber inspirasi. Artinya, pemimpin mendefinisikan visi untuk mencpai masa depan, menantang pengikut dengan standar yang tinggi, berbicara optimis dan antusias, dan memberikan dorongan dan makna untuk hal-hal yang perlu dilakukan; 3) Merangsang kemampuan intelektual pengikut untuk berkembang dengan menjadi kritisdalam berpikir. Artinya, pemimpin mengajak pengikut mengevaluasi asumsi, pandangan yang lama, tradisi, dan keyakinan, agar dapat merangsang prespektif baru dan menemukan cara baru dalam melakukan sesuatu, dan mendorong pengikut agar mengekspresikan ide-ide dan prioritas baru; 4) mengembangkan diri para pengikut secara individual. Artinya, pemimpin berinteraksi dengan pengikut sebagai individu, mempertimbangkan kebutuhan unik mereka, kemampuan dan aspirasi, serta mendengarkan mereka dengan penuh perhatian, berfokus lebih lanjut pada ranah pengembangan mereka, menyarankan, mengajar dan meng-coach mereka (Munthe, 2015: 273-274).

Menurut Bass (1990) bahwa ada tiga cara seorang pemimpin transformasional memotivasi anak buah, yaitu dengan cara: 1) mendorong anak buah untuk lebih menyadari arti penting hasil usaha; 2) mendorong anak buah untuk mendahulukan kepentingan kelompok; dan 3) meningkatkan kebutuhan anak buah yang lebih tinggi seperti harga diri dn aktualisasi diri. Judge dan Locke (1993) menegaskan bahwa gaya kepemimpinan merupakan salah satu faktor penentu kepuasan kerja. Anak buah atau karyawan kebanyak keluar dari tempat bekerja lebih banyak, disebabkan tidak puas terhadap kondisi kerja, karena anak buah merasa bahwa pimpinan tidak memberi kepercayaan kepadanya, tidak ada keterlibatan anak buah dalam pembuatan keputusan, pimpinan berlaku tidak obyektif dan tidak jujur pada anak buah. Dengan pemikiran lain bahwa alasan utama anak 
buah meninggalkan organisasi disebabkan karena pemimpin gagal memhami anak buah dan tidak memperhatikan kebutuhankebutuhan mereka.

Di madrasah, kepala madrasah memiliki peran sangat penting dalam proses meningkatkan mutu madrasah. Mulyasa (2011: 159) menegaskan "Gaya kepemimpinan kepala madrasah berpengaruh terhadap kinerja tenaga kependidikan di madrasah untuk meningkatkan produktivitas kerja demi mencapai tujuan dan mewujudkan visi menjadi aksi" Sementara itu Sergiovanni menyatakan bahwa seorang kepala madrasah yang ideal harus menyadari tugastugas utama sebagai administrator. "They consider to be the essenstial roles and tasks of administrators. Planning, organizing, leading and controlling" (Sergiovanni, 1991: 17). Sedangkan Bass dan Riggio (2006) menunjukkan empat komponen pokok model kepemimpinan transformasional. Keempat komponen pokok itu adalah: 1 . Idealized influence; merupakan perilaku pemimpin yang menghasilkan rasa hormat (respect) dan rasa percaya diri (trust) dari orang-orang yang dipimpinnya. 2. Inspirational motivation; pada di- mensi ini pemimpin transformasional mampu memberi motivasi dan menginspi- rasi para pengikutnya melalui tantangan dan pemberian makna dalam pekerjaan mereka. 3. Intellectual stimulation; pada di- mensi ini pemimpin transformasional memberikan dorongan kepada para peng- ikutnya untuk lebih inovatif dan kreatif. 4. Individualized consideration; pada dimensi ini pemimpin transformasional mampu memberi perhatian yang besar kepada masing-masing pengikut (Jabar, 2014: 125-126).

Berbicara soal mutu atau yang popular manajemen mutu, tentu mencakup perpaduan semua fungsi dan proses terkait tahap-tahap yang berbeda, seperti; desain, perencanaan, produksi, distribusi dan pelayanan. Ukuran keberhasilan manajemen mutu adalah kepuasan pelanggan, dan cara untuk mencapainya adalah dengan melalui desain sistem dan peningkatan secara terus menerus. Manajemen mutu pada prinsipnya adalah menjalankan fungsi manajemen secara maksimal dengan menggerakkan seluruh organisasi, aktivitas dan individu di setiap tingkat untuk mencapai kualitas (A1Azhar, 2010: 262).

Manajemen peningkatan mutu merupakan konsep manajemen sekolah/madrasah dalam penyelenggaraan pendidikan, diharapkan tuntutan dan dinamika masyarakat dapat memberikan perubahan yang lebih baik seiring dengan lajunya perkembangan, dalam menjawab permasalahan-permasalahan pengelolaan pendidikan pada tingkat sekolah/madrasah. Manajemen mutu merupakan sebuah kajian mengenai bagaimana sebuah pendidikan persekolahan harus dikelola secara efektif dan efisien, dan berkeadilan untuk mewujudkan mutu pendidikan (Minarti, 2011: 320).

Hadari Nawawi (2005: 46) mengatakan bahwa manajemen mutu terpadu adalah manajemen fungsional dengan pendekatan yang secara terus menerus difokuskan pada peningkatan kualitas, agar produknya sesuai dengan standar kualitas dari masyarakat yang dilayani dalam pelaksanaan tugas pelayanan umum dan pembangunan masyarakat. Setiap pekerjaan dalam manajemen mutu terpadu harus dilakukan melalui tahapan perencanaan, persiapan (termasuk bahan dan alat), pelaksanaan teknis dengan metode kerja/cara kerja yang efektif dan efisien, untuk menghasilkan produk berupa barang atau jasa yang bermanfaat bagi masyarakat.

Manajemen mutu merupakan sebuah konsep yang mengaplikasikan berbagai prinsip mutu untuk menjamin suatu produk barang/jasa yang memiliki spesifikasi mutu sebagaimana diterapkan secara menyeluruh. Pendekatan manajemen mutu dilakukan secara menyeluruh yaitu mulai dari input, proses, output dan outcome. Hal ini dilakukan secara berkelanjutan dengan menunjukkan upaya mewujudkan mutu lembaga merupakan bagian kerja keseharian bukan sesuatu yang bersifat temporal (Tim Dosen Administrasi Pendidikan UPI, 2010: 295). Dalam konteks manajemen mutu madrasah dipahami sebagai unit layanan jasa, artinya pelayanan pembelajaran. Jasa layanan ini menyangkut berbagai pihak yang dilayani madrasah antara lain: pelanggan internal berupa guru, pustakawan, laboran, teknisi dan tenaga administrasi. Sedangkan pelanggan tersebut terdiri atas pelanggan primer berwujud siswa, pelanggan skunder berwujud orang tua, pemerintah, dan masyarakat, lalu pelanggan tersier yang berwujud pemakai/penerima lulusan (Martini, 2011: 355).

Tim merupakan bagian dari konsep dasar manajemen mutu, artinya para anggota organisasi pendidikan dan satuan pendidikan bekerja sama dalam kelompok-kelompok kecil untuk satu tujuan yang ditetapkan dengan fokus mewujudkan kualitas pelanggan belajar, yang berimplikasi pada 
kualitas lulusan sebagai produk dari pendidikan. Kualitas manajemen bagi sebuah institusi pendidikan tampak pada produktifitas manajemen kelembagaan. Produktifitas adalah ukuran seberapa baik seoranga manajer mengubah input/sumber daya menjadi output, produk atau hasil yang berguna sebagai hasil sumber daya (Indana, 2017: 69. Lingkungan organisasi bidang pendidikan yang bersifat non profit, menurut Hadari Nawawi (2005: 47) bahwa ukuran produktivitas organisasi bidang pendidikan dapat dibedakan sebagai berikut: 1 . Produktivitas internal, berupa hasil yang dapat diukur secara kuantitatif, seperti jumlah atau prosentase lulusan sekolah, atau jumlah gedung dan lokal yang dibangun sesuai dengan persyaratan yang telah ditetapkan; 2. Produktivitas eksternal, berupa hasil yang tidak dapat diukur secara kuantitatif, karena bersifat kualitatif yang hanya dapat diketahui setelah melewati tenggang wktu tertentu yang cukup lama.

Secara umum, mutu memiliki makna derajat keunggulan suatu produk (hasil kerja) baik berupa barang ataupun jasa, baik yang tangible ataupun yang intangible. Kemudian hubungannya dengan pendidikan, pengertian mutu adalah mengacu pada proses pendidikan dan hasil pendidikan itu sendiri. Artinya, dalam proses pendidikan yang bermutu meliputi berbagai input, antara lain; materi ajar, metode pembelajaran, sarana sekolah, tenaga kependidikan, sarpras dan sumber daya yang lain. Manajemen sekolah, dukungan kelas berfungsi untuk mensinergikan semua komponen dalam proses pembelajaran, termasuk kegiatan ekstra yang telah diprogramkan (Murtadho, 2012: 101).

Mutu hasil pendidikan dalam konteks ini menyangkut berbagai prestasi yang telah dicapai madrasah dalam kurun waktu tertentu, setiap akhir semester dan setiap akhir tahun pelajaran. Hasil pendidikan tersebut bisa berupa hasil tes potensi akademik semisal ulangan umum, dan ujian nasional. Prestasi juga bisa dalam bidang lain seperti prestasi bidang olah raga, bidang kesenian, bidang ketrampilan-ketrampilan tambahan lainnya. Termasuk dalam kategori prestasi adalah berupa intangible (kondisi yang tidak bisa dipegang) semisal tingkat kedisiplinan, adanya saling hormatmenghormati, kebersihan dan kegotongroyongan. Agar proses-proses yang ideal seperti itu tidak salah arah, maka peningkatan mutu tersebut dirumuskan sedemikian rupa oleh kepala madrasah, target dan sasarannya jelas yang akan dicapai dalam kurun waktu yang telah ditentukan (Murtadho, 2012: 102).

\section{TEMUAN DAN PEMBAHASAN}

1). Kepemimpinan Kepala MA Matholiul Huda Bugel Kedung Jepara

Kepala madrasah Aliyah Matholi'ul Huda Bugel Jepara dalam memimpin madrasah memiliki nilai-nilai yang diperjuangkan. Adapun nilai-nilai dimaksud antara lain: terbuka, displin, rasa memiliki, kerjasama, pengabdian, sabar, jujur, dan menciptakan suasana nyaman. Kepemimpinan kepala madrasah Aliyah Matholi'ul Huda Bugel Jepara telah membangun rasa percaya dengan para guru dan karyawan. Wujud kepercayaan itu dibangun melalui keteladanan kepala madrasah yang dapat dipercaya. Kesesuaian antara apa yang diucapkan dan yang dilakukan oleh kepala madrasah Aliyah Mtaholi'ul Huda Bugel Jepara telah terealisasi dengan baik. Bentuk membangun kepercayaan dalam diri guru dan karyawan, dalam konteks ini kepala madrasah Aliyah Matholi'ul Huda Bugel Jepara memberikan kesempatan kepada guru dan karyawan untuk mengeluarkan pendapat, memberikan kesempatan untuk ikut ambil bagian dalam tugas-tugas dan tanggung jawab, juga mengikuti berbagai pelatihan. Melalui pemberian kepercayaan kepada guru dan karyawan, terbentuklah suatu relasi dan komunikasi yang memiliki kedekatan dengan baik. Relasi seperti itu dibangun antara atasan dan bawahan sebagai wujud kedekatan dan kebersamaan guna meraih prestasi.

Kepala madrasah Aliyah Matholi'ul Huda Bugel Jepara memiliki tanggung jawab dan sebagai ujung tombak dalam menentukan arah dalam mewujudkan dan meningkatkan mutu madrasah. Peningktan mutu madrasah tersebut meliputi mutu guru, mutu pendampingan peserta didik dalam menggunakan waktu secara efektif. Untuk menambah daya tarik madrasah, MA Matholi'ul Huda Bugel Jepara memberi perhatian penuh pada kegiatan ekstrakurikuler. Peningkatan mutu madrasah sangat dirasakan oleh wali murid atau wali santri dilingkungan madrasah Aliyah Matholi'ul Huda Bugel Jepara.

Penelitian kepemimpinan transformasional kepala madrasah dalam meningkatkan mutu madrasah ini dilaksanakan di MA Matholi'ul Huda Bugel Jepara. Nilai-nilai kepemimpinan transformasional yang dikaji meliputi empat aspek, seperti yang dijelaskan oleh Bass dan Ringgio (2006: 6-7) yaitu: Idealized influence, Inspirational motivation, 
Intellectual stimulation, dan Individualized consideration (Jabar, 2014: 130).

\section{Aspek Idealized Influence}

Idealized Influence atau pengaruh ideal memiliki empat variabel yang mampu menjadi contoh yang baik bagi guru dan karyawan, memiliki standar moral dan etika yang tinggi, menghargai bawahan, memberi kepercayaan penuh kepada anak buah dalam melakukan tugas. Kepala madrasah sangat menjujung tinggi tentang standar moral dan etika. Kepala madrasah mewujudkan kondisi dan suasana keterbukaan dalam lingkungan madrasah, sehingga masing-masing pribadi bisa saling mengenal (ta'aruf) satu dengan lainnya. Kepala madrasah mampu mengambil keputusan terbaik untuk kepentingan madrasah yang di dasarkan pada beberapa pertimbangan nilai yang dipercayainya.

Saling percaya antara kepala madrasah dengan para guru dan tenaga kependidikan lainnya selalu dibangun dilingkungan MA Matholi'ul Huda Bugel Jepara. Sebagaimana diungkapkan Ngizuddin (wakil kepala bidang kurikulum: 43 th) bahwa setiap hari sabtu madrasah mencanangkan program "infaq-shadaqah". Para guru dilingkungan madrasah pada jam awal telah mengkordinir peserta didik di kelas tersebut dimana ia mempunyai jam mengajar untuk melakukan pengumpulan dana infaq-shadaqah tersebut, kemudian dikumpulkan ke karyawan madrasah/staf tata usaha pada saat waktu istirahat (Wawancara tanggal 02 April 2018). Kepala madrasah Aliyah Matholi'ul Huda Bugel juga berusaha melakukan penyesuaian antara apa yang dikatakan dengan apa yang dilakukan. Seperti yang diungkapakan Abd. Hamid (Ka.TU: 45 th) bahwa kepala madrasah menginstruksikan agar semua guru ikut andil dalam program penggalian dana untuk pembangunan gedung madrasah. Dalam kegiatan ini kepala madrasah memberikan contoh keteladan memberikan infaq-shadaqah pertama sekali, kemudian diikuti oleh para guru dan karyawan dilingkungan madrasah Aliyah Matholi'ul Huda Bugel . Adapun besaran infaqshadaqah kepala madrasah 2.000.000,-, guru rata-rata 1.000.000,-, dan karyawan 750.000,- (Wawancara tanggal 23 April 2018).

\section{Inspirational motivation}

Inspirational motivation atau motivasi inspirasi yang memiliki dua dimensi, memiliki waktu untuk berkomunikasi dengan anak buah. Artinya, kepala madrasah mampu memberikan motivasi kepada guru dan karyawan untuk melaksanakan tugas-tuganya dengan baik. Komunikasi kepala madrasah Aliyah Matholi'ul Huda Bugel Jepara tersebut dijalankan secara formal dan kekeluargaan. Menurut Sarwadi (Kepala Madrasah, 48 th) bahwa, setiap akhir bulan madrasah selalu melakukan rapat guru dan karyawan, untuk mendengar masalah-masalah yang telah terjadi selama satu bulan, baik terkait dengan kegiatan pembelajaran, kegiatan kesiswaan, kehumasan, maupun sarana prasarana, utamanya dalam kelas (Wawancara tanggal 29 Mei 2018). Pertemuan guru dan karyawan tersebut, disamping mendengar laporan para guru, dan wali kelas, juga inspirasi para gauru dan karyawan. Hal demikian dilakukan oleh kepala madrasah, karena pertemuan tersebut juga merupakan sarana bagi kepala madarasah untuk memotivasi para guru dan karyawan sebagai anak buah dalam melaksanakan tugas (Wawancara tanggal 01 April 2018).

\section{Intellectual stimulation}

Intellectual stimulation atau stimulasi intelektual yang terdiri dari dua variabel: mampu memacu timbulnya kreasi dan inovasi dari anak buah. Artinya, kepala madrasah dalam memecahkan masalah madrasah melibatkan guru dan karyawan sebagai anak buah. Sarwadi (Kepala Madrsaah, 48 th) menyatakan bahwa, dalam mengatasi guru guru yang sering tidak hadir dan hanya mengirimkan tugas di kelas, ia selaku kepala madrasah melakukan komunikasi dengan empat orang wakil kepala madrasah, yaitu bpk Ngizuddin selaku wakil kepala bidang bidang kurikulum, bpk Mudlofar selaku wakil kepala bidang kesiswaan, bpk Habib Muhlis selaku wakil kepala madrasah bidang humas, dan bpk Zainuddin selaku wakil kepala madrasah bidang sarana prasaran (Wawancara: tanggal 29 Mei 2018). Kepala madrasah melakukan kegiatan tersebut untuk mencari titik temu dan kesepakatan dalam menyelesaikan permasalahan guru yang kurang tertib tersebut. Prilaku kepala madarasah yang menjadi suri tauladan dan panutan, bisa berkomunikasi dengan para guru dan karyawan lainnya dengan baik dan berempati. Hal ini mampu memacu terwujudnya krasi dan inovasi darai bawahan walaupun belum secara keseluruhan mampu berinovasi secara maksimal (Wawancara tanggal 01 April 2018). 
Individualized consideration.

Nilai keempat ini bisa disebut konsiderasi individu. Aspek ini memiliki empat variabel; mampu berempati terhadap karyawan, mampu menjadi pelatih da guru yang baik bagi karyawan dalam proses poduksi, mau mendengar keluhan karyawan, dan mementingkan kebutuhan karyawan. Kepala madrasah Aliyah Matholi'ul Huda Bugel dalam bersikap tidak hanya sebagai pemimpin, tetapi ia juga bertindak sebagai teman dan orang tua bagi para guru dan aryawan dilingkungan madrasah Aliyah Matholi'ul Huda. Sebagaimana diungkapkan oleh Mansur (guru tetap, 31 th) bahwa, kepala madrasah pada bulan April 2016 saat akan dilakukan visitasi assesor akreditasi madarasah, hampir setiap malam bersama dengan guru dan staf TU melakukan kegiatan lembur menyiapkan berbagai data yang perlu disempurnakan. Hal ini dilakukan secara akrab seperti tidak ada sekat antara atasan dan bawahan (Wawancara: tanggal 29 Mei 2018). Kondisi seperti ini membuat rasa nyaman bagi anak buah dilingkungan madrasah Aliyah Matholi'ul Huda Bugel, utamanay dalam menyelesaikan masalah. Kepala madrasah mengutamakan kebutuhan dan kepentingan bawahan, utamanya terkait dengan peningkatan mutu di madrasah (Wawancara tanggal 05 April 2018).

\section{2). Peningkatan Mutu MA Matholiul Huda Bugel Kedung Jepara}

Dalam penelitian ini, disamping menjelaskan tentang kepemimpinan transformasional, juga ada hubungan erat dengan pengembangan mutu, baik mutu dalam aspek akademik maupun non akademik.

Terkait hasil observasi dan wawancara secara mendalam, peneliti dapat memberikan pemahaman bahwa peningkatan mutu pendidikan di MA Matholi'ul Huda Bugel Kedung Jepara terlaksana dengan baik. Hal ini dapat dibuktikan dengan penerapan prinsip-prinsip manajemen mutu antara lain; customer focused organization (orientasi pada pelanggan), leadership (kepemimpinan), involvement of people (keterlibatan orangorang), process aproach (pendekatan proses), system aproach to management (perbaikan secara berkelanjutan), factual aproach to decision making (pengambilan keputusan dengan pendekatan fakta), mutually beneficial supplier-relationship (membangun yang saling menguntungkan).
Salah satu prinsipnya adalah customer focused organization (orientasi pada pelanggan) yang bisa dilakukan madrasah aliyah Matholi'ul Huda Bugel Kedung Jepara yaitu berusaha memenuhi kebutuhan para siswa dan orang tua murid. Melihat banyaknya jumlah peserta didik pada madrasah tersebut maka kebutuhan dan keinginan mereka juga beragam. Jumlah total peserta didiknya sejumlah 1.095 siswa baik kelas X, XI dan kelas XII. Terkait dengan kebutuhan peserta didik yang menyangkut dengan penyaluran minat dan bakat, maka madrasah menyediakan berbagai program ekstrakurikuler, sebagaimana yang dinyatakan oleh wakil kepala madrasah bidang kesiswaan Ahmad Mudlofar (42 th) berikut:

"Madrasah telah memprogramkan kegiatan ekstrakurikuler, antara lain; pramuka; training dakwah; bimbingan kajian kitab salaf; engglish club; Arabic club; PMR; qira'ah al-Qur'an bi-tagghani; tata boga; sepak bola; bola voly; pencak silat, dan bulu tangkis. Melalui 11 jenis program kegiatan ini diharapkan madrasah bisa menjaring dan menyalurkan minat dan bakat peserta didik di lingkungan madrasah ini. Masing-masing kegiatan oleh kepala madrasah dipercayakan kepada guru pembimbing atau guru pelatih sesuai dengan komptensinya masing-masing. Jadwal pelatihan sudah diatur sedemikian rupa, jadi kesekian kegiatan ekstra tidak akan mengalami dumpyuk/ tabraan. Oleh karenanya, berkat kegigihan guru pelatih dan keaktifan anak-anak, maka dari sekian program kegiatan ekstra ini pada tahun pelajaran 2014/2015 peserta didik kami ada yang meraih prestasi yaitu pencak silat dengan kejuaraan tingkat Nasional menduduki perinkat juara I bernama Dinda Lusiana (Wawancara: tanggal 5 April 2018). Keberadaan pendidikan termausk ekstrakurikuler di sebuah lembaga madrasah bisa berjalan secara baik karena memiliki beberapa komponen dasar, seperti keberadaa, guru, peserta didik, kurikulum, bangunan fisik, media pembelajaran dan sebagainya. Namun dari semua itu yang dianggap mendasar ialah faktor manusia, dalam konteks ini adalah guru dan karyawan, mereka merupkan faktor penentu dalam dunia pendidikan (Munir, t.t,: 6). Karena pendidikan sebagai usaha untuk membina dan mengembangkan pribadi manusia dari aspek rohaniah dan jasmaniah, berlangsung secara bertahap (Arifin, 2009: 2).

Setiap lembaga pendidikan tidak lepas dari berbagai tantangan dan hambatan. Persoalan 
tantangan dan hambatan ini juga terjadi di Madrasah Aliyah Matholi'ul Huda Bugel Kedung Jepara, sehingga madrasah harus mampu mewujudkan sumber daya manusia yang berkualitas dan bermutu yang mampu menyelesaikan berbagai problem-problem kemadrasahan.

Madrasah sebagai salah satu institusi pendidikan merupakan lembaga yang berfungsi sebagai "agent of change", yang bertugas untuk membangun anak didik agar sanggup memecahkan masalah nasional dan memenangkan persaingan internasional. Penyelenggaraan pendidikan dan pengajaran di madrasah aliyah Matholi'ul Huda Bugel Kedung Jepara, seperti yang dinyatakan kepala madrasah Sarwadi (48 th) berikut:

"Madrasah kami berupaya perlunya mewujudkan orientasi pada pembentukan manusia yang kompeten dan berakhlakul karimah. Selain itu, madrasah kami juga memiliki kegiatan bimbingan bagi peserta didik yang memiliki potensi lebih dalam rangka peningkatan mutu, antara lain; bimbingan belajar khusus mata pelajaran yang dilombakan seperti mapel sosiologi, biologi, fisika, kimia, geografi dan matematika. Untuk mengetaui keterpenuhan kebutuhan peserta didik dan keinginan wali murid, madrasah juga melakukan pertemuan bersama orang tua murid 2 kali dalam satu tahun (awal dan akhir tahun pelajaran). Pertemuan tersebut dilakukan guna mengetahui sejauh mana kepuasan orang tua dengan model pelayanan yang dilakukan madrasah aliyah Matholi'ul Huda Bugel Kedung Jepara ini" (Wawancara tanggal 01 April 2018).

Artinya, madrasah menyelenggarakan program pembelajaran tambahan guna memenuhi pemetaan kebutuhan anak didik khususnya pada jurusan IPA dan IPS, antara lain memacu terpenuhinya mapel-mapel tertentu seperti sosiologi, biologi, fisika, kimia, geografi dan matematika. Terbukti pada tahun pelajaran 2016-2017 siswa siswi dari berbagai jurusan telah banyak yang menempati kejuaraan, baik tingkat regional maupun nasional, antara lain: Arif Sudirman siswa kelas XI jurusan IPA merupakan salah satu peserta didik unggul yang berhasil masuk lomba olimpiade Fisika tingkat nasional. Upaya madrasah dalam memacu peningkatan mutu peserta didik dengan langkah-langkah setrategis, salah satunya menggunakan pendampingan teman sebaya dan tutor para ahli dari luar madrasah. Artinya siswa kls $\mathrm{X}$ yang berpotensi mempunyai keunggulan dalam mata pelajaran fisika dan IPA diberikan pembimbingan dan pendampingan oleh teman kakak kelasnya dalam memacu semangat mereka.

Menurut Ahmad Mudlofar (42 th) selaku wakil kepala madrasah bidang kesiswaan mengatakan bahwa untuk mewujudkan mutu madrasah, terkait dengan kedisiplinan peserta didik, MA Matholi'ul Huda Bugel memberlakukan jam awal masuk 07.00 pulang jam 14.00 WIB. Melalui pantauan bidang wakil kepala bidang kesiswaan, bagi peserta didik yang kehadirannya terlambat dari ketentuan tata tertib madrasah, seperti; tidak memakai seragam madrasah, berkuku panjang, peserta didik wanita yang memakai perhiasan berupa emas, merokok (ana putra), anak putra tidak memakai kopyah, maka diberikan pengarahan oleh guru piket (sebagai tangan panjang guru BP) diharpakan anak-anak tersebut menjadi sadar akan adanya pemberlakuan tata tertib madrasah. Dengan pemantauan dan bimbingan seperti itu rata-rata tingkat ketertiban menjadi lebih baik (Wawancara tanggal 5 April 2018).

Zainuddin (40 th) selaku wakil kepala madrasah bidang Humas mengatakan, dalam mewujudkan mutu kebersihan madrasah, MA Matholi'ul Huda Bugel menempati posisi sebagai madrasah bersih dan sehat tingkat Kelompok Kerja Madrasah Aliyah (KKMA) 02 Kabupaten Jepara. Kebersihan madrasah meliputi; ruang kelas, halaman madrasah, kamar kecil dan lingkungan madrasah secara umum, juga merupakan bagian dari unggulan mutu MA Matholi'ul Huda Bugel (Wawancara tanggal 06 Mei 2018). Sebagaimana Agus (43 th) petugas kebersihan madrasah mengatakan untuk meningkatkan kebersihan di madarasah telah disediakan bak sampah di depan masing-masing ruang kelas. Bagi peserta didik yang piket harian, sebelum pulang sekolah, mereka melakukan kebersihan ruang kelas masing-masing. Pembuangan sampah dilakukan serentrak dalam bak-bak khusus. Sampah plastik tidak dicampur dengan sampah kertas. Hal ini sudah merupakan budaya yang sudah melekat pada diri peserta didik di MA Matholi'ul Huda Bugel. Untuk pembuangan akhir disediakan kendaraan roda empat (truk sampah) guna untuk pembuangan dan pengangkutan sampah yang ada di madrasah ke tempat pembuangan akhir sampah daerah Jepara (Wawancara tanggal 06 Mei 2018).

Menurut Sudarwan Danim, bahwa hasil (output) pendidikan dinyatakan memiliki mutu unggul jika mampu melahirkan keunggulan akademik dan ekstrakurikuler 
pada peserta didik yang dinyatakan lulus untuk satu jenjang pendidikan atau menyelesaikan pembelajaran tertentu. Upaya peningkatan mutu di MA Matholi'ul Huda Bugel Kedung Jepara menurut Ngizuddin (43 th) diwujudkan dengan predikat "sangat baik" dengan bukti adanya keunggulan hasil UN dalam 3 tahun terakhir mulai Tahun Pelajaran 2014/2015, 2015/2016, 2016/2017 dengan peserta didik yang mengikuti ujian nasional selalu memperoleh kelulusan $100 \%$ dengan rata-rata nila 8.50 (Wawancara tanggal 02 April 2018). Pada tahun pelajaran tersebut, khususnya jurusan Agama telah meraih prestasi terbaik tingkat Provinsi Jawa Tengah secara berturut-turut. Pada tahun pelajaran 2016/2017 pelaksanaan ujian nasional di MA Matholi'ul Huda Bugel Kedung Jepara sudah mengikuti program ujian nasional yang berbasis komputer dengan hasil kelulusan 100\% (Wawancara tanggal 02 April 2018).

Sedangkan mutu akademik yang telah dicapai oleh peserta didik MA Matholi'ul Huda Bugel Kedung Jepara menurut Ngizuddin (43 th) pada tahun pelajaran 2016-2017 siswa siswi dari berbagai jurusan banyak yang menempati kejuaraan baik tingkat regional maupun nasional, antara lain: Arif Sudirman siswa kelas XI jurusan IPA merupakan salah satu peserta didik unggul yang berhasil masuk lomba olimpiade Fisika tingkat nasional. Upaya madrasah dalam memacu peningkatan mutu peserta didik dengan langkah-langkah setrategis, salah satunya menggunakan pendampingan teman sebaya dan tutor para ahli dari luar madrasah. Artinya siswa kls X yang berpotensi mempunyai keunggulan dalam mata pelajaran fisika dan IPA diberikan pembimbingan dan pendampingan oleh teman kakak kelasnya dalam memacu semangat mereka (Wawancara tanggal 21 April 2018).

Ahmad Mudlofar (42 th) mengatakan prestasi non akademik yang telah diraih MA Matholi'ul Huda Bugel kedung Jepara juga cukup banyak, antara lain: level kejuaraan tingkat Kabupaten dan provinsi antara lain; juara 1 mata pelajaran sosiologi oleh Nayirotul Abhariyah, juara 1 mata pelajaran biologi diraih Dewi Nur Izzah Fairuza, Juara 1 mata pelajaran fisika diraih Aliyyul Wafa, juara 1 mata pelajaran kimia diraih Vika Yasaro Nur Hidayah, Juara 1 Lct. oleh Ariella Wardatun Nabilah, Lila Fitrotun Nada, Saidatur Rahmah, Juara 3 mata pelajaran geografi diraih Fakhira Akmal Fikriya, juara mata pelajaran matematika oleh Novita Lutviyatun, Juara harapan 3 mata pelajaran akutansi oleh Nafidza Zulfa Ahmad, dan olimpiade mata pelajaran keNU-an yang meraih juara 3 oleh Alifatun Hasanah (Wawancara tanggal 5 April 2018).

\section{KESIMPULAN}

Penelitian tentang kepemimpinan transformasional kepala madrasah dalam meningkatkan mutu madrasah di madrasal Aliyah Matholi'ul Huda Bugel Jepara dapat disimpulkan berikut ini: kepala madrasah memiliki nilai kepemimpinan yang diyakini bisa diperjuangkan untuk membangun kemajuan dan mutu madarasah. Adapun nilai-nilai itu adalah:

Nilai kepemimpinan transformasional yang meliputi empat aspek yaitu: Idealized Influence atau pengaruh ideal, Inspirational motivation atau motivasi inspirasi, Intellectual stimulation atau stimulasi intelektual, Individualized consideration atau konsiderasi individu.

Kepemimpinan kepala madrasah Aliyah Matholi'ul Huda Bugel Jepara telah membangun rasa percaya dengan para guru dan karyawan. Wujud kepercayaan itu dibangun melalui keteladanan kepala madrasah yang dapat dipercaya. Kesesuaian antara apa yang diucapkan dan yang dilakukan oleh kepala madrasah Aliyah Mtaholi'ul Huda Bugel Jepara telah terealisasi dengan baik. Bentuk membangun kepercayaan dalam diri guru dan karyawan, dalam konteks ini kepala madrasah Aliyah Matholi'ul Huda Bugel Jepara memberikan kesempatan kepada guru dan karyawan untuk mengeluarkan pendapat, memberikan kesempatan untuk ikut ambil bagian dalam tugas-tugas dan tanggung jawab, juga mengikuti berbagai pelatihan. Melalui pemberian kepercayaan kepada guru dan karyawan, terbentuklah suatu relasi dan komunikasi yang memiliki kedekatan dengan baik. Relasi seperti itu dibangun antara atasan dan bawahan sebagai wujud kedekatan dan kebersamaan guna meraih prestasi.

Mutu MA Matholi'ul Huda Bugel Kedung Jepara dengan predikat "sangat baik" dengan bukti adanya keunggulan hasil UN dalam 3 tahun selalu memperoleh kelulusan $100 \%$ dengan rata-rata nila 8.50. Pada tahun pelajaran tersebut, khususnya jurusan Agama telah meraih prestasi terbaik tingkat Provinsi Jawa Tengah secara berturut-turut. Peserta didik juga telah banyak meraih kejuaranan lomba sains, antara lain: level Kabupaten dan provinsi, juara 1 mata pelajaran sosiologi, juara 1 mata pelajaran biologi, Juara 1 mata pelajaran fisika, juara 1 
mata pelajaran kimia, Juara 1 Lct., Juara 3 mata pelajaran geografi, juara 2 mata pelajaran matematika, Juara harapan 3 mata pelajaran akutansi dan olimpiade mata pelajaran ke-NU-an meraih juara 3.

\section{DAFTAR PUSTAKA}

Abdul Munir, Seni Mengelola Lembaga Pendidikan Islam, Ciputat: Arta Karya Indonesia.

Al Azhar A, Peranan Total Quality Manajemen (TQM) Dalam Meningkatkan Daya Saing, Pekbis Jurnal, Vol.2, No.1, Maret 2010.

Ali Murtadho,Memperkokoh Kualitas Pendidikan Madrasah Berbasis Manajemen Mutu Terpadu (TQM), Jurnal: Forum Tarbiyah, Vol. 10, No. 1, Juni 2012.

Muzayyin Arifin, 2009, Filsafat Pendidikan Islam, Jakarta: Bumi Aksara.

Nur Zazin, 2011, Gerakan Menata Mutu Pendidikan, Jogjakarta: Ar- Ruzz Media.

Nurul Indana, Implementasi Total Quality Management (TQM) dalam Meningkatkan Mutu pendidikan (Studi Kasus di MTs Salafiyah Syafi'iyah Tebuireng), Jurnal Al-Idaroh, Vol. 1 No. 1 Maret 2017.

Sri Minarti, 2011, Manajemen Sekolah, Jogjakarta: Ar-Ruzz Media.

Tim Dosen Administrasi Pendidikan UPI, 2010, Manajemen Pendidikan, Bandung: Alfabeta.

Tukiman, Cepi S. Abdul Jabar, Implementasi Kepemimpinan Transformasional Kepala Sekolah Dalam Meningkatkan Mutu Sekolah di SD Kansius Sengkan Kabupaten Sleman, Jurnal Akutansi Manajemen Pendidikan, Volume 2, No. 1, 2014. 